洞爺湖温泉源に及ほした1977有珠山噴火の影繁

山口久之助* ・堀津多三郎*・沼尾秀章*

\title{
The Influence of the Activity of the Usu Volcano in 1977 on the Toya Hot Springs, Hokkaido
}

Hisanosuke YAMAGUCHI, Tasaburo Horitsu and Hideaki NUMAO

\begin{abstract}
Variations in temperature, water level and chemical composition of the Toya hot springs due to the activity of the Usu double volcano in 1977 were investigated. Following results were obtained in 1978.

Temperatures of hot springs investigated increased gradually during a series of the phreatic explosions that followed on the initial explosions.

The water level of them rised more or less in the area keeped relatively high temperature.

By the variation of chemical composition in water, the hot springs in the Toya area can be divided into two groups; one is characterized by the increase in both chloride concentration and water temperature; the othes by the increase in bicarbonate content but the decrease in $\mathrm{pH}$.
\end{abstract}

\section{まえがき}

昭和新山の生誕以来30余年間鳴りをひそめていた有珠山は，1977年 8 月 7 日朝突如として大爆発を 開始した。そしてその日から8日間にわたって大小併せ16回の爆発を繰返し，遠近各地に大量の降灰 をもたらした。その後, 翌年の春まではさしたる爆発もなく小康状態を続けたが， 5 月末頃から活発 化の兆しをみせはじめ，7月15日に至って中小の激しい爆発を再開した。この春以降の爆発は前年夏 のそれと様式が異り，マグマ水蒸気爆発と称されるものである。こうした水蒸気爆発は1978年10月 5 日を最後として終息したが，しかし地下のマグマの動きは停止に至らず, 有珠火口原に台頭した新山 
は，崩れて変形した大有珠と肩を立心゙，そして小有珠を見下すまでて成長するなど，地盤変動や地震 は依然として続いている。この間, 温泉街をはじめ周辺地域は, 大量の降灰とそれの二次的泥流の来 襲, あるいはまた地殸変動による建造物の破壊など, 甚大な被害をらけた。こうした被害のうちには 源泉井や，給湯パイプラインの破損も含まれ，一時は観光地洞爺湖温泉の再起が危まれるほどとなっ た。

今回の有珠山噴火については, 北海道大学をはじめ多くの機関によって, 火山学上あるいは防㷋工 学上のさまざまな調査研究が行われているが, 著者らは遅ればせながら1978年以降, 噴火による温泉 源への影響調査と併せ, 涌出機構の解明を目的として研究に着手した。この報告は, 1978年中にえら れた結果をまとめたるのである。

\section{1. 洞爺湖温泉の概況}

洞賗湖温泉は洞爺カルデラの南壁下に位置しており, 隣接の壮憼温泉と併せると, 宿泊施設の収容 人員ならびに利用者数に执いて，また総揚湯量に执いて，登別・定山渓・湯の川などと規模を競いあ ら，北海道屈指の温泉地である。

この温泉の発端は, 1910年（明治43年）の有珠火山活動の所産として西丸山北簏の湖岸で涌出をみ たもの，とされている。そして初期の頃は, 湖岸近くに浴槽を設けて自然涌出状態で利用に供されて いた。その後, 温泉地の拡大にともない湖岸から離れてポンプ揚湯井が設けられるようになって, 湖 岸での自然涌出口はもとより, 湖岸寄りの揚湯井に扎いても次第に泉温低下をきたして廃井を余儀な くされ，それに代わる源泉をより高所で求めるといら悪循環がしばらく続いた。こうした源泉の変遷 については石川（1963）の報文傽しい。

源泉井の変遷には多くのトラブルもあったが，その苦い経験を通じて源泉の共同管理方式の確立が 促され，1959年競合による源泉の変遷に終止符がうたれたのである。眓 1 に源泉位置の変遷のあらま しを示す。

現在, 洞爺湖温泉地域には利用源泉が15口あり，いずれもボーリング井である。ボーリング深度は 地盤高の相違によって 40〜115 m とまちまちだが，ストレーナ管挿入位置は地下水面下 $10 \mathrm{~m}$ 前後と注 ぼ一様である。ケーシングロ径は150～200血で，水中モータポンプによって総量約 13,000 l/分が汲 上げられている。泉温は図 1 に示すように山寄りの源泉で $50^{\circ} \mathrm{C}$ 前後, 湖寄りの源泉で $30^{\circ} \mathrm{C}$ 前後とな っている。

\section{2. 洞爺湖温泉地域の水理地诈}

\section{1 地 形}

今回の火山活動の中心となった有珠山は, 沖積世にはいってから洞筋カルデラの南縁に噴出した複 式火山で, 図 2 に示すよ5に山頂部に直径約 $1.7 \mathrm{~km}$ の火口をもつ。この火口内には, 大有珠・小有珠 の既成溶岩円頂丘と，今回の活動によって生じた新山ならびに爆裂火口などがある。一方，有珠火口 をとりまく線から外側は外輪山と称され，溶岩流・火砕流・泥流などの流走面を配し裙野を広げてい る。この外輪山の中腹あるいは縁辺には, 金比羅山・西丸山・四十三山・東丸山など, いくつもの潜 在円頂丘が瘤状に突出して, 山容に变化を与えている。これらの潜在円頂丘のうち, 活動の様子を文 


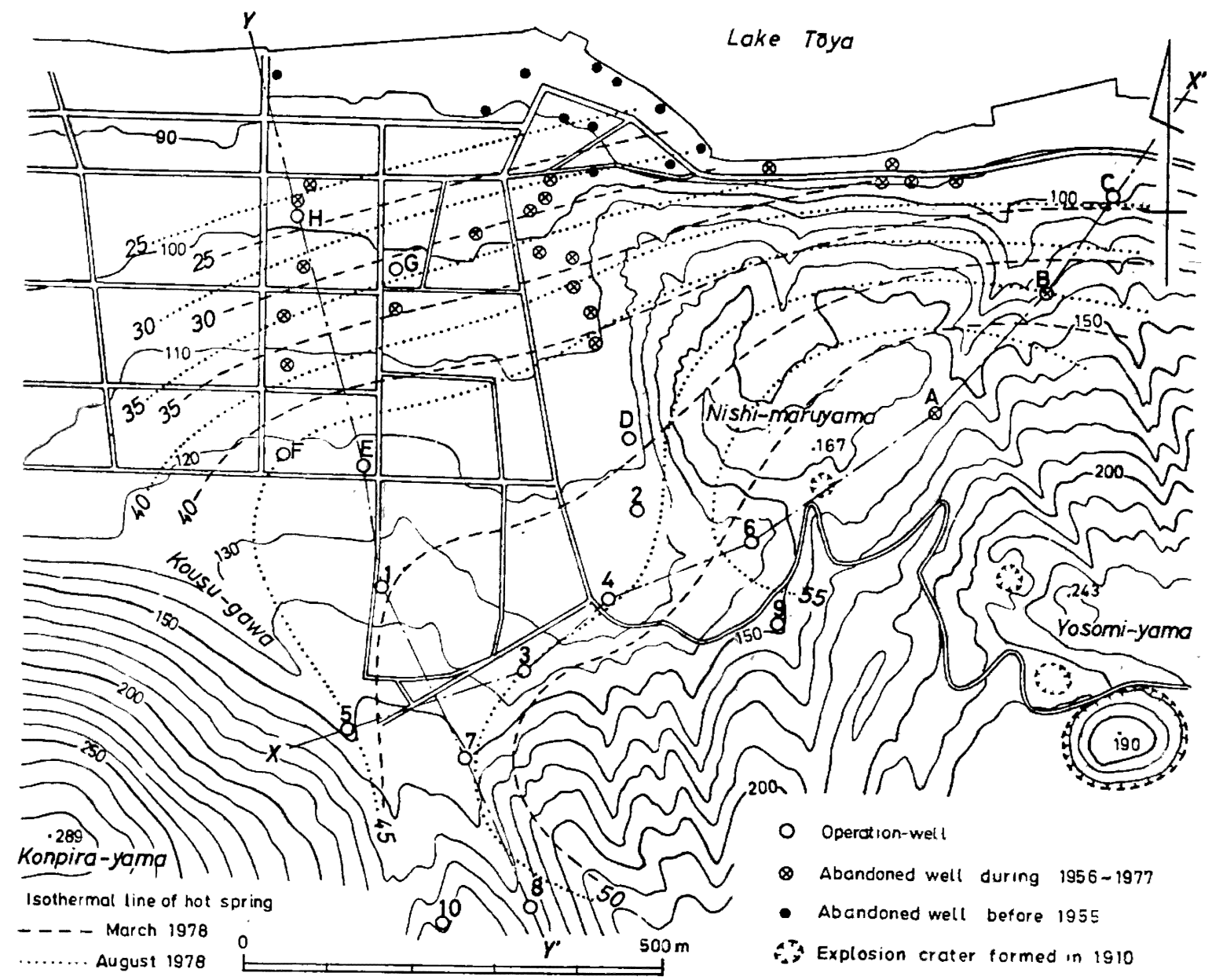

図一 1 洞翁湖温泉の源泉井位置と泉温分布

献にとどめているのは四十三山だけで，その他については時代が古く，活動に関する記録はない。

外輪山と潜在円頂丘の山脚から湖畔へかけては扇状地と崖錐が形成されている。洞爺湖温泉街は,

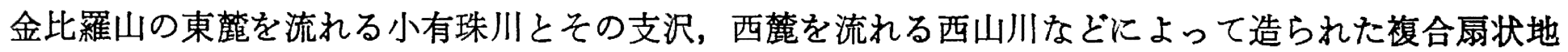

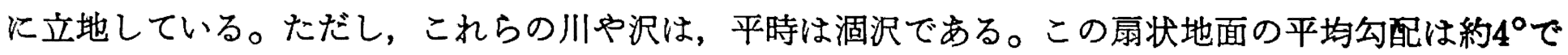
あるが，汀線から先の湖底面は $30^{\circ}$ 近い勾配で不連続的に急傾斜し，沖合い約 $150 \mathrm{~m}$ に至って水深 40 mとなり，それから緩斜面に移っている。

\section{2 基 盤 岩}

洞爺湖温泉地域に扣ける有珠山の基盤岩は，太田（1956）によってノットュ溶岩と名づけられた， 新第三紀鮮新世の火山岩類とみられる。本岩類は, 虹田から温泉街へ通ずる国道沿いの山地や西山川 左岸の山腹では, 両輝石安山岩と火山确屑岩の累重からなっている。そして, これと岩相上で同定可 能なるのが，金比羅山北東麓の 5 号源泉のボーリングで深度 95〜 $151 \mathrm{~m}$ 間に介在する。このボーリン グは, 図 3 に示すよらに深度 $240 \mathrm{~m}$ まで行われた本地域最深のものであるが, $87 \mathrm{~m}$ 以深では泉脈に当 らず，結局それ以浅で採湯するように仕上げられた。

洞爺湖温泉地域では，その背後にあるはずのカルデラ壁は有珠山体でお括われて見ることができな いが，隣接地域の地形と地質からは，図2に示した付近を通過しているかのよらに推察される。るち ろん，実際には図のように単純な円孤ではなく，そこに有珠山の出現を許した構造弱線の発達が考え 


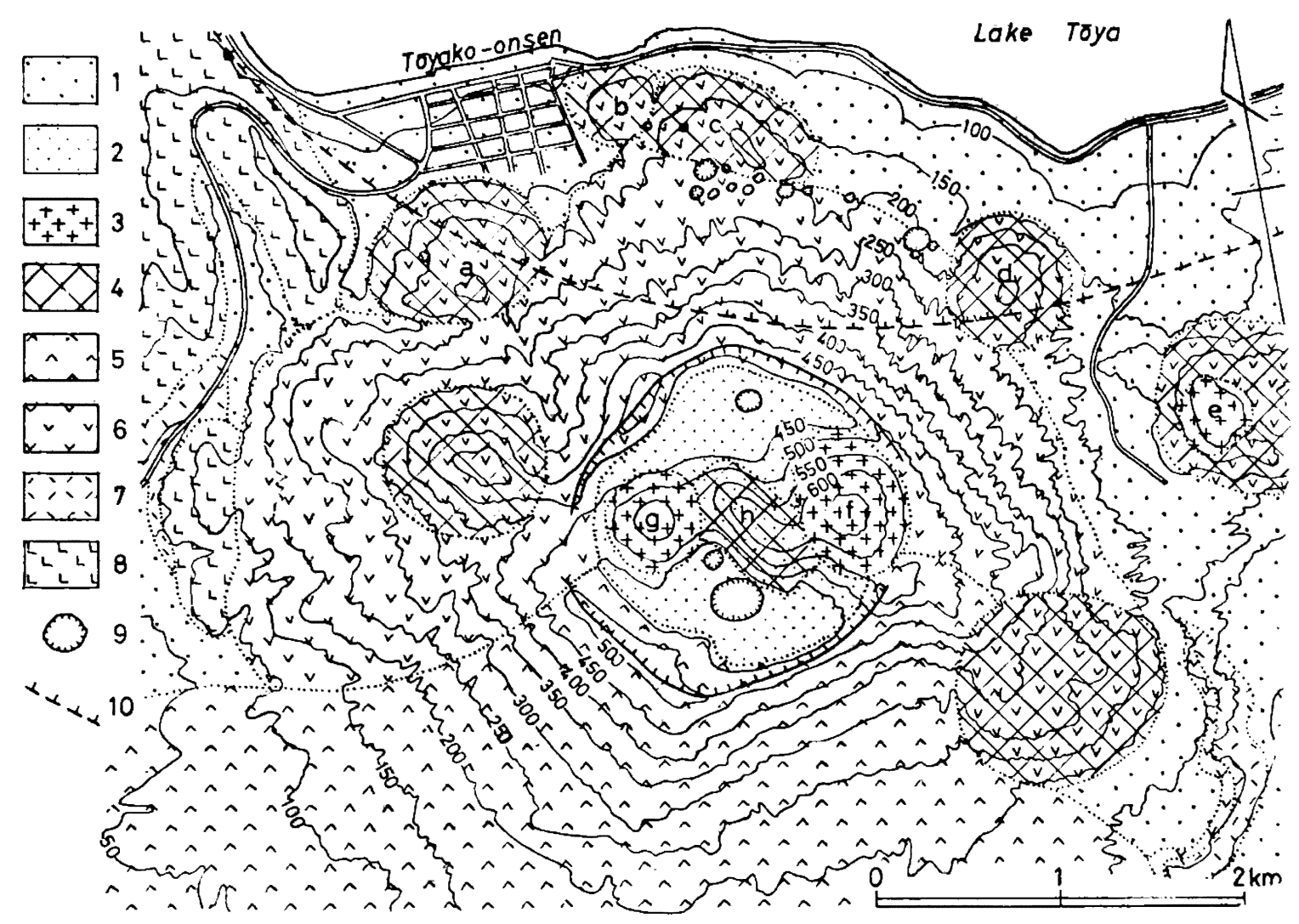

\section{図一2 有珠山の地質}

1:崖錐及び扇状地堆積物 $2:$ 火口原堆積物 $3:$ 円頂丘溶岩 $4:$ 潜在円頂丘 $5:$ 文政泥流 $6:$ 外輪山溶岩 $7:$ 洞爺軽石流堆積物 $8:$ 新第三紀火山岩類 $9:$ 爆裂火口 $10:$ カルデラ壁推定線

$\mathrm{a}$ ：金比羅山 $\mathrm{b}$ ：西丸山 $\mathrm{c}$ ：四十三山 $\mathrm{b}$ ：東丸山 $\mathrm{e}$ ：昭和新山 $\mathrm{f}$ ：大有珠 $\mathrm{g}$ : 小有珠 $\mathrm{h}$ ：'77新山

られる。そしてまた，基盤岩の上限面がカルデラ壁の内側で急激に深まっていることはいらまでもな い。

\section{3 温泉貯留層}

洞爺湖温泉の熱源は，四十三山をはじめ西丸山や金比羅山などを形成させた潜在溶岩体とその放出 ガスにあるとみられている。そして，主要な温泉貯留層は疑もなく外輪山溶岩である。本溶岩は，厚 さ $10 \mathrm{~m}$ 以内の玄武岩溶岩とスコリアとの累重からる。全般に艘裂や節理が発達し，また気孔に富むる のるみられる。外輪山溶岩全体の厚さは確認できないが，ボーリング結果や分布状態からは200m以 内と推定される。

いま，数ある源泉井のうち，地質の記録があるもの，あるいはストレーナ位置の記録があるものを 拾って，図1の $\mathrm{X}$ - $\mathrm{X}^{\prime}$ 及び $\mathrm{Y}-\mathrm{Y}^{\prime}$ の断面を描くと図4 のようになる。図に扎いて，各ボーリング孔 の下部に記入した数字はストレーナ位置または孔底深度を示し，水位記号は1978年 6 月の実測位置を 示す。また，図の下段に示した泉温は，6号源泉とB源泉については平均孔内温度であり，それ以外 は揚湯温度である。なお，A源泉は現在廃井となっていて検温不能たが，1961年には $81^{\circ} \mathrm{C} ， 1962$ 年 


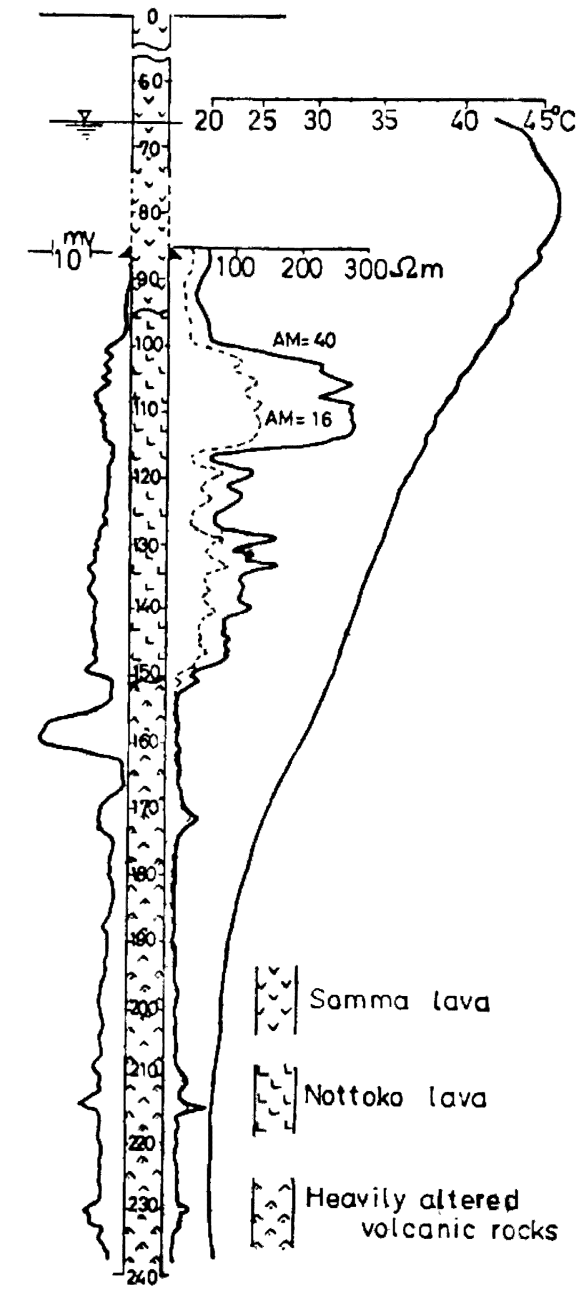

図一－５号源泉井の地質と物理検層
には76 $\mathrm{C}$ と記録されている（石川：1963）。このA源泉は， 高温かつ低水面のためエアリフト揚湯井として仕上け゚られた が，スヶールの付着が著しく，短命に終わった。

ところで，溶岩流が水域に突入した際，そこで自破碎をお こして，一部または大半がスラッグ状となるのはよく知られ た現象である。それで，外輪山溶岩が盛んに迸出した当時の 湖水面標高が現在のとれと大差なかったとすると, 湖水準以 下に伏在する外輪山溶岩は陸上のものよりも強く自破碎して いるであろらし，かつまた，金比羅山・西丸山・四十三山な ぞの潜在円頂丘の形成に際しては，外輪山溶岩と基盤岩とは ，撓曲・圧砕・裂開などを激しくらけたであるう。こうした 理由で，本地域の地下に伏在する外輪山溶岩は頗る多孔質で から，亀裂に富み，高い透水性を具えていることが推察され る。そしてこのことは，ボーリングや揚湯試験によってる実 証されている。

\section{4 扇状地堆積物}

扇状地堆積物は，それの機序からは土石流及び泥流堆積物 であって，淘汰不良の火山砂祭が主体となっている。この堆 積物の透水性は全般に高いが，その下位の外輪山溶岩よりは 贫る。層厚は扇頂から扇端へと增し，扇端へ近づくと湖底堆 積物も介入して，全体で40m前後に達すると考劣られる。湖 底堆積物は主に細砂で, シルトや础を扭む。

\section{5 温泉の倵存機構}

洞爺湖温泉の賦存機構については従来，多くの報告がなされている（鈴木ほか：1957, 福富ほか： 1957, 石川：1963）。それらを要約すると, 温泉の貯留形態は層状泉であって, 湖水及び降水の浸透 にもとづく地下水が地下深部に执いて四十三山その他の潜在溶岩体とその放出がスで加熱され，これ が浮上して湖岸方向へ流れている，といらのが定説となっている。そして，以降にのべる筆者らの調 查・研究結果も，基本的にはこの定説を追認するものといえる。

\section{1978水蒸気爆発による泉温・水位等の变動}

\section{1 観測方法と観則値}

本地域の源泉井のうちには，地壳変動で損傷をらけたとか，以前からの泉温低下で休止中とか，そ の他の理由で水中モータポンプを撤去しているものが数本ある。そこで著者らは，孔内計測が可能な 6 号源泉と B 源泉を選び，水位・泉温・比電導度などの定期観測を1978年 5 月下旬から開始した。こ の観測中, 偶然にも一連の水蒸気爆発が起ったのである。

上記の観測種目のらち，泉温は東邦電探 $\mathrm{E} T-6$ 型水温計により，比電導度は手製の 3 電極セルに 
より，そして水位はサーキットテスターによった。表 1 ～4 に泉温と比電導度の観測データを摘約し て揭げる。煩鎖なデータをあえて揭げたのは，温泉眝留層中における温水塊の挙動をみやすくするた めにほかならない。たと圭ば，最高温部に着目すると，これは常に一定の深度と温度とを保っていな い。井戸内だけでの対流現象は考光にくいことから，温水塊は温泉貯留層内をたえす浮動しているこ と，おそらくは対流を生じていることがうかがわれる。

表一 16 号源泉の 孔内水温度分布 $\left({ }^{\circ} \mathrm{C}\right)$

\begin{tabular}{|c|c|c|c|c|c|c|c|c|c|c|c|c|}
\hline $\begin{array}{c}\text { 月日 } \\
\text { 深度 } \\
(\mathrm{m})\end{array}$ & 5. 24 & 6.3 & ${ }^{*}{ }^{*} 10$ & 6.25 & 7.1 & 7.15 & 8.15 & $\begin{array}{c}* \\
8.27\end{array}$ & 9.8 & 9.29 & 10.21 & 11.10 \\
\hline 54 & 47.8 & 56.6 & 56.6 & 55.1 & 56.4 & 56.9 & 54.1 & 59.2 & 59.0 & 60.0 & 59.8 & 59.4 \\
\hline 55 & 48.4 & 56.7 & 56.8 & 56.0 & 56.6 & 57.1 & 56.0 & 59.4 & 59.3 & 60.3 & 59.9 & 59.8 \\
\hline 56 & 49.2 & 56.7 & 56.8 & 56.4 & 56.8 & 57.2 & 57.8 & 59.6 & 59.6 & 60.5 & 60.0 & 60.0 \\
\hline 57 & 50.0 & 56.7 & 56.9 & 56.6 & 56.8 & 57.2 & 57.8 & 59.7 & 59.7 & 60.6 & 60.1 & 60.2 \\
\hline 58 & 51.5 & 56.7 & 57.0 & 56.9 & 56.9 & 57.3 & 59.1 & 59.7 & 59.7 & 60.6 & 60.1 & 60.2 \\
\hline 59 & 56.1 & 56.6 & 57.0 & 56.9 & 57.0 & 57.4 & 59.2 & 59.8 & 59.7 & 60.7 & 60.2 & 60.3 \\
\hline 60 & 56.6 & 56.5 & 57.0 & 57.0 & 57.1 & 57.4 & 59.2 & 59.9 & 59.8 & 60.6 & 60.2 & 60.3 \\
\hline 61 & 56.6 & 56.4 & 57.0 & 57.0 & 57.1 & 57.4 & 59.3 & 60.0 & 59.8 & 60.5 & 60.2 & 60.3 \\
\hline 62 & 56.8 & 56.3 & 57.0 & 57.0 & 57.2 & 57.4 & 59.4 & 60.1 & 59.8 & 60.5 & 60.3 & 60.3 \\
\hline 63 & 56.8 & 56.2 & 57.0 & 57.0 & 57.2 & 57.4 & 59.6 & 60.1 & 60.0 & 60.6 & 60.4 & 60.4 \\
\hline 64 & 56.8 & 56.0 & 56.9 & 57.0 & 57.2 & 57.4 & 59.6 & 60.2 & 60.1 & 60.6 & 60.4 & 60.4 \\
\hline 65 & 56.8 & 55.9 & 56.9 & 57.0 & 57.2 & 57.4 & 59.6 & 60.2 & 60.1 & 60.6 & 60.4 & 60.4 \\
\hline 66 & 56.8 & 55.9 & 56.8 & 57.0 & 57.2 & 57.4 & 59.6 & 60.2 & 60.2 & 60.6 & 60.4 & 60.3 \\
\hline 67 & 56.8 & 55.9 & 56.6 & 56.8 & 57.1 & 57.3 & 59.2 & 60.3 & 60.2 & 60.6 & 60.3 & 60.3 \\
\hline 68 & 56.8 & 55.9 & 56.5 & 56.8 & 56.9 & 57.2 & 59.1 & 60.2 & 60.2 & 60.5 & 60.2 & 60.2 \\
\hline 69 & 56.5 & 55.9 & 56.4 & 56.5 & 56.8 & 57.1 & 59.1 & 60.2 & 60.2 & 60.5 & 60.0 & 60.0 \\
\hline 70 & 56.4 & 55.9 & 56.1 & 56.5 & 56.8 & 57.1 & 58.9 & 60.2 & 60.2 & 60.4 & 59.9 & 59.9 \\
\hline
\end{tabular}

表一2 6 号源泉の孔内水比電導度分布 $\left(X 10^{-2} \mho / \mathrm{cm}\right)$

\begin{tabular}{c|r|r|r|r|r|r|r|r|r|r|r|r}
\hline $\begin{array}{c}\text { 深度 } \\
(\mathrm{m})\end{array}$ & 5.24 & 6.10 & 6.17 & 6.25 & 7.1 & 7.8 & 7.15 & 8.15 & 8.27 & 9.8 & 9.22 & 9.29 \\
\hline 63 & 107 & 98 & 204 & 208 & 175 & 149 & 143 & 161 & 152 & 208 & 192 & 172 \\
64 & 110 & 98 & 192 & 208 & 175 & 154 & 143 & 156 & 152 & 228 & 192 & 172 \\
65 & 110 & 110 & 185 & 196 & 161 & 154 & 143 & 156 & 152 & 238 & 192 & 172 \\
66 & 110 & 110 & 182 & 196 & 161 & 154 & 143 & 154 & 152 & 238 & 192 & 172 \\
67 & 110 & 110 & 192 & 182 & 159 & 149 & 143 & 154 & 152 & 228 & 192 & 172 \\
68 & 110 & 110 & 192 & 182 & 161 & 149 & 139 & 154 & 147 & 244 & 192 & 172 \\
69 & 110 & 110 & 192 & 175 & 159 & 149 & 149 & 145 & 147 & 232 & 182 & 169 \\
70 & 103 & 110 & 182 & 159 & 145 & 159 & 139 & 145 & 147 & 244 & 182 & 169 \\
\hline
\end{tabular}


表一 3 B 源泉の 孔内水温度分布 $\left({ }^{\circ} \mathrm{C}\right)$

\begin{tabular}{|c|c|c|c|c|c|c|c|c|c|c|}
\hline $\begin{array}{l}\text { 深度 } \\
(\mathrm{m})\end{array}$ & $6 .{ }^{*} 16$ & 8.15 & 8. 26 & 9.2 & 9.8 & 9. 22 & 9. 29 & 10.21 & 10.28 & 11.10 \\
\hline 48 & 48.8 & 48.5 & 48.0 & 49.1 & 50.2 & 50.5 & 50.8 & 50.9 & 51.5 & 52.6 \\
\hline 49 & 49. 2 & 49.0 & 49.5 & 49.3 & 50.4 & 51.1 & 51.4 & 51.6 & 52.1 & 52.8 \\
\hline 50 & 49. 2 & 49.3 & 49.7 & 49.5 & 50.5 & 51.2 & 51.4 & 51.8 & 52.1 & 52.8 \\
\hline 51 & 49. 2 & 49.5 & 49.7 & 49.5 & 50.5 & 51.2 & 51.3 & 51.8 & 52.1 & 52.7 \\
\hline 52 & 49.3 & 49.5 & 49.7 & 49.5 & 50.5 & 51.1 & 51.1 & 51.7 & 52.0 & 52.5 \\
\hline 53 & 49.5 & 49.5 & 49.5 & 49.3 & 50.4 & 50.8 & 51.0 & 51.5 & 51.8 & 52.2 \\
\hline 54 & 49.4 & 49.5 & 49.5 & 49.2 & 50.4 & 50.6 & 50.6 & 51.0 & 51.4 & 51.6 \\
\hline 55 & 49.4 & 49.5 & 49.1 & 49.0 & 50.1 & 50.1 & 50.1 & 59.5 & 50.8 & 51.0 \\
\hline 56 & 49. 2 & 49.0 & 48.5 & 48.2 & 49.1 & 49.5 & 49. 3 & 49. 3 & 49.6 & 50.0 \\
\hline 57 & 48.8 & 48.5 & 47.2 & 47.4 & 48.2 & 48.5 & 43.2 & 48.9 & 48.5 & 49.0 \\
\hline 58 & 47.8 & 48.0 & 45.9 & 46.5 & 47.2 & 47.7 & 47.5 & 47.5 & 47.5 & 47.9 \\
\hline 59 & 47.0 & 47.0 & 45.6 & 45.8 & 46.5 & 46.7 & 46.6 & 46.7 & 46.8 & 47.2 \\
\hline 60 & 47.0 & 47. 2 & 45.6 & 45.6 & 46.5 & 46.7 & 46.6 & 46.7 & 46.8 & 47.2 \\
\hline
\end{tabular}

表一 4 B 源泉の孔内水此電導度分布 $\left(\times 10^{-2} \mho / \mathrm{cm}\right)$

\begin{tabular}{c|c|c|c|c|c|c|c|c}
\hline $\begin{array}{c}\text { 深度 }_{(\mathrm{m})}^{\text {月日 }} \\
\text { ( }\end{array}$ & 6.16 & 8.15 & 8.20 & 8.20 & 9.2 & 9.8 & 9.22 & 9.29 \\
\hline 53 & 220 & 120 & 150 & 147 & 222 & 189 & 147 & 152 \\
54 & 175 & 120 & 141 & 143 & 250 & 185 & 167 & 152 \\
55 & 167 & 120 & 141 & 137 & 250 & 179 & 161 & 152 \\
56 & 182 & 118 & 141 & 137 & 250 & 185 & 161 & 143 \\
57 & 175 & 115 & 133 & 128 & 250 & 188 & 145 & 143 \\
58 & 164 & 112 & 133 & 125 & 244 & 145 & 143 & 132 \\
59 & 161 & 109 & 130 & 125 & 200 & 147 & 143 & 122 \\
60 & 164 & 104 & 130 & 125 & 200 & 147 & 143 & 122 \\
\hline
\end{tabular}

\section{2 泉温及び比電導度の垂直分布}

表 1 ～4のちち，*印を付した月日の観測データをプロットすると，図 5 及び図 6 のよらになる。 まず図 5 の 6 号源泉についてみると，上下間での温度較差は約 $1 \mathrm{deg}$ と小さいが，水蒸気爆発後は 全体に約 $3 \mathrm{deg}$ 上昇している。また，比電導度が爆発後ストレーナ部分において温度上昇の影響を上 回る変化を呈しているのは，溶存成分の濃度上昇を示唆している。 
次に，図6のB源泉についてみると，上下間での温度較差が目立つ。とくに11月10日では $6 \operatorname{deg} に$ むなっている。このよらに顕著な較差が生じたのは，温泉貯留層中での温泉水の対流が旺盛になった ことを示唆している。また，比電導度が水蒸気爆発期のさなかにかえって低下したのは，後述の水位 の変動と併世考兄ると，湖岸深部方向からの地下水流入の促進にもとづくすのと思われる。

なお因 7 は，1号源泉の浚渫工事の機会をとらえ，その前後に打いて計測したデータを示したもの であって，最高温部が水面下およそ16mと深い位置に出現しているのが注目される。

\section{3 水位・泉温及び比電導度の経時変化}

今回の噴火以来，洞爺湖温泉地域に打いても，上昇・沈下・横ずれなど複雑な地盤变動が続いてい る。そのため, 源泉水位の経時変化をみるには, 地盤高变動量を水位観測値から除去しなければなら ない。各源泉地点の変動量を正確にとらえることはむずかしいが，6号源泉については，その南西約 $180 \mathrm{~m}$ に位置する 4 号源泉近傍に設けられた，北海道大学有珠火山観測所の水準測量点の日変動量を 地盤高補正値として，水面標高を定めることとした。この水準点の日变動量は，水位観測期間中殆ど 一定で， $+1.55 \mathrm{~mm}$ である。ただし B源泉については，火山観測所のデータによると地盤沈下帯に所在 するらしいが，その変動量は僅少とみて地盤高補正を省略した。なお，6号及びB源泉の地盤標高は

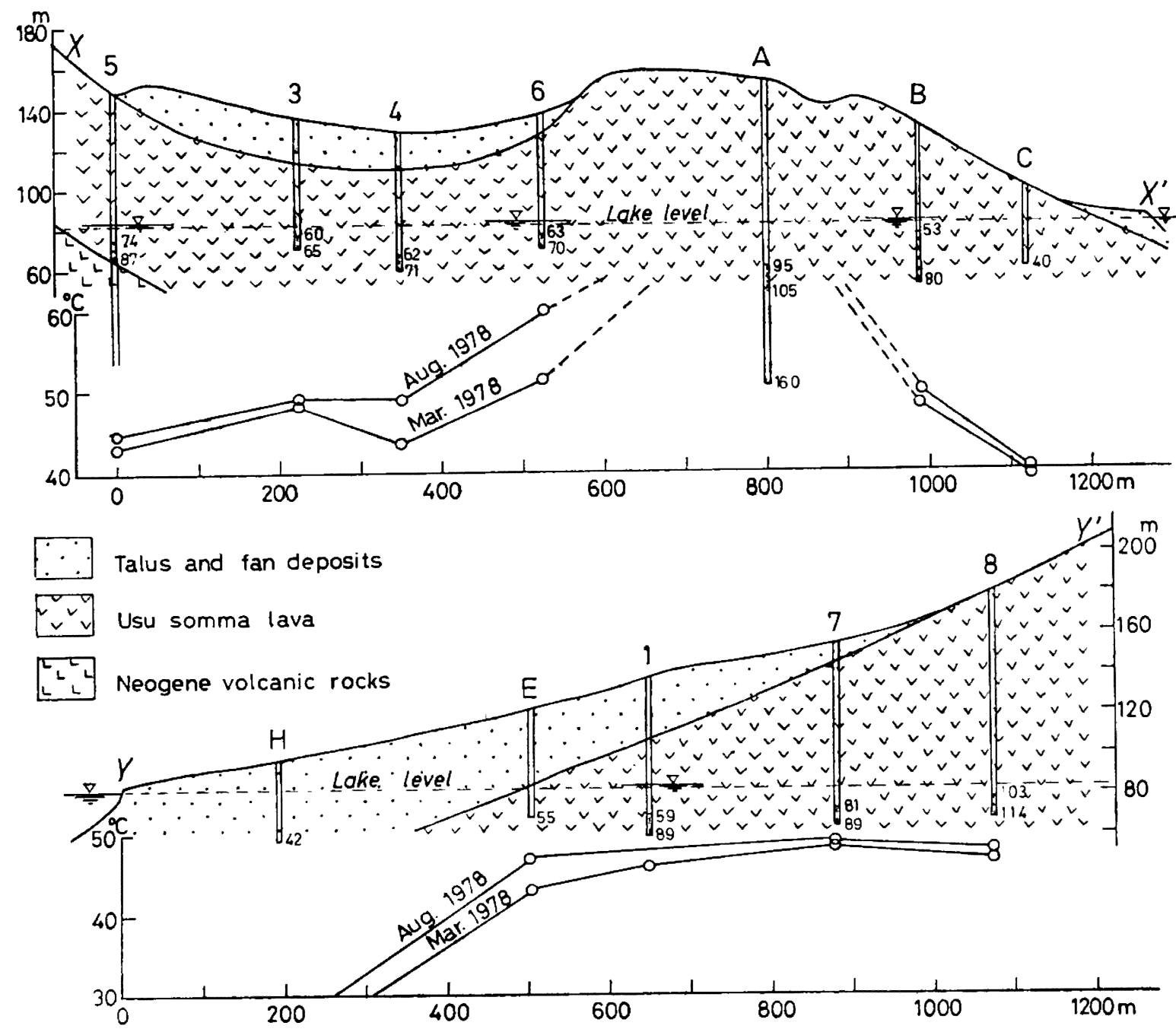

図一 $4 \quad \mathrm{X}-\mathrm{X}$ 伋び $\mathrm{Y}-\mathrm{Y}$ 断面 


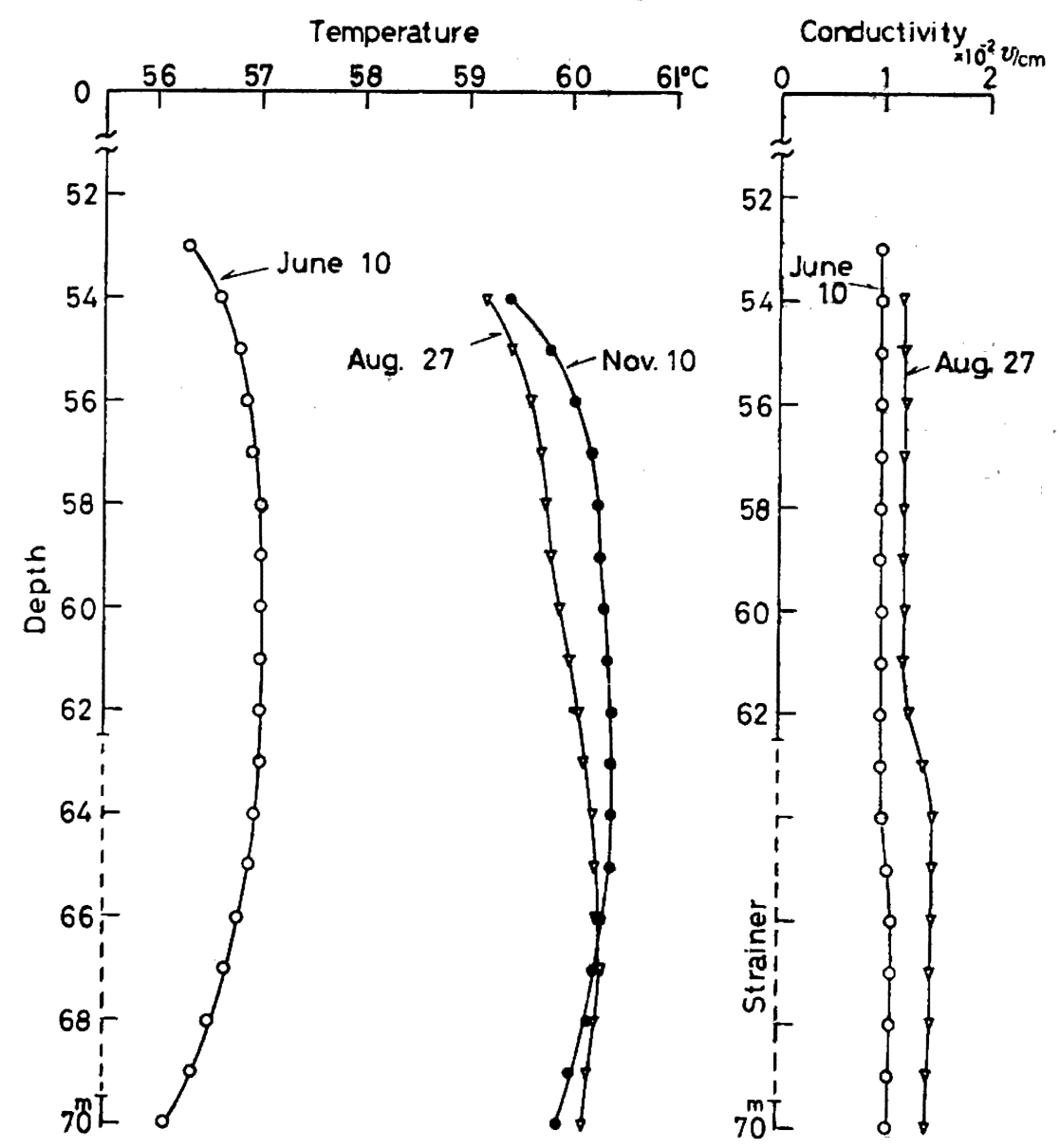

図一 56 号源泉の泉温及び比電導度の垂直分布
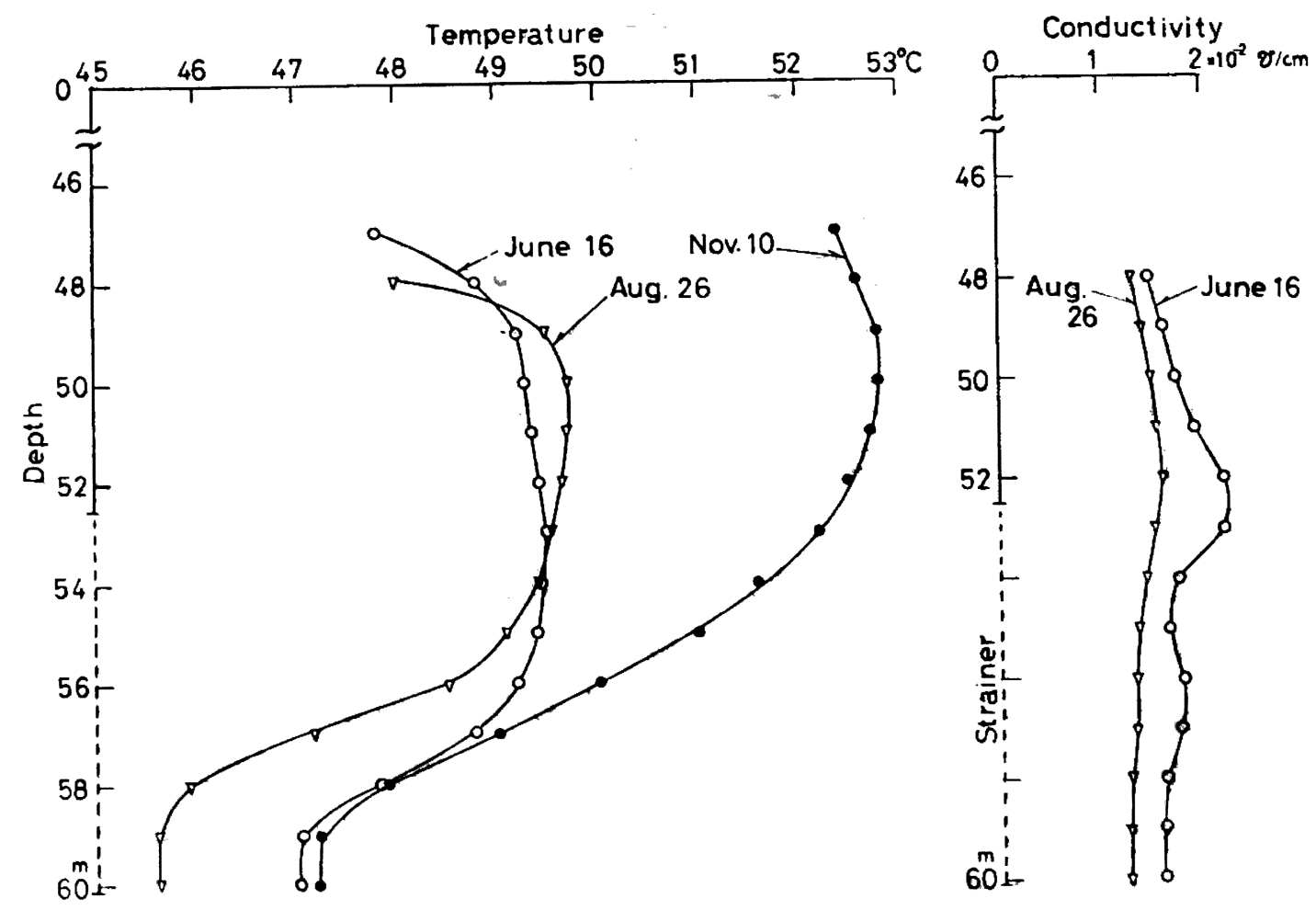

図一6 B 源泉の泉温及び比電㮍度の垂直分布 
洞爺湖水面を基準面として実施した水 準測量の結果から定めたもので，11月 23日測量当日の湖水面標高は，北電洞 爺発電所の観測值で83, 333mである。 洞爺湖の水面は, 北電洞爺発電所の放 水量と虹田発電所の取水量, それに湖 水流域の降水量と蒸発散量とのあいだ の水収支関係によって，变動している が，長期的には図 8 亿示すよ5に83.0 $\pm 0.5 \mathrm{~m}$ と, 打よそ $1 \mathrm{~m}$ の変動幅でバ ランスが保たれている。ただし，1978 年夏以降で変動が小さい主因は，発電 の停止にある。

さて，表 1 及び 2 におる各観測日 ごとの泉温及び比電導度の最高值と， 表 5 の水面標高との経時変化をみると 図9のよらになる。この図において泉 温は，7月中旬に始まった水蒸気爆発 を契機としておよそ 2 か月間に $57^{\circ} \mathrm{C}$ ら $61^{\circ} \mathrm{C}$ 一と $4 \mathrm{deg}$ も上昇したが，爆発 活動の終息とともに上昇を停止してい る。次に水位は，爆発期の約 1 か月前 から上昇しはじめ，爆発開始直前にピ 一クに達し，爆発期にはいるとともに徐々に 低下に移っている。そして爆発が終息してか らも低下傾向は続いて，爆発期前よりもか兄 って低下している。一方, 比電導度は, 爆発 開始の約半月前と, 爆発最盛期頃に高まりを きたしている。なお，図の下段の爆発雲の高 さは気象庁の観測報告を図化したもので，当 然のことながら夜間や雨天のものは欠測とな

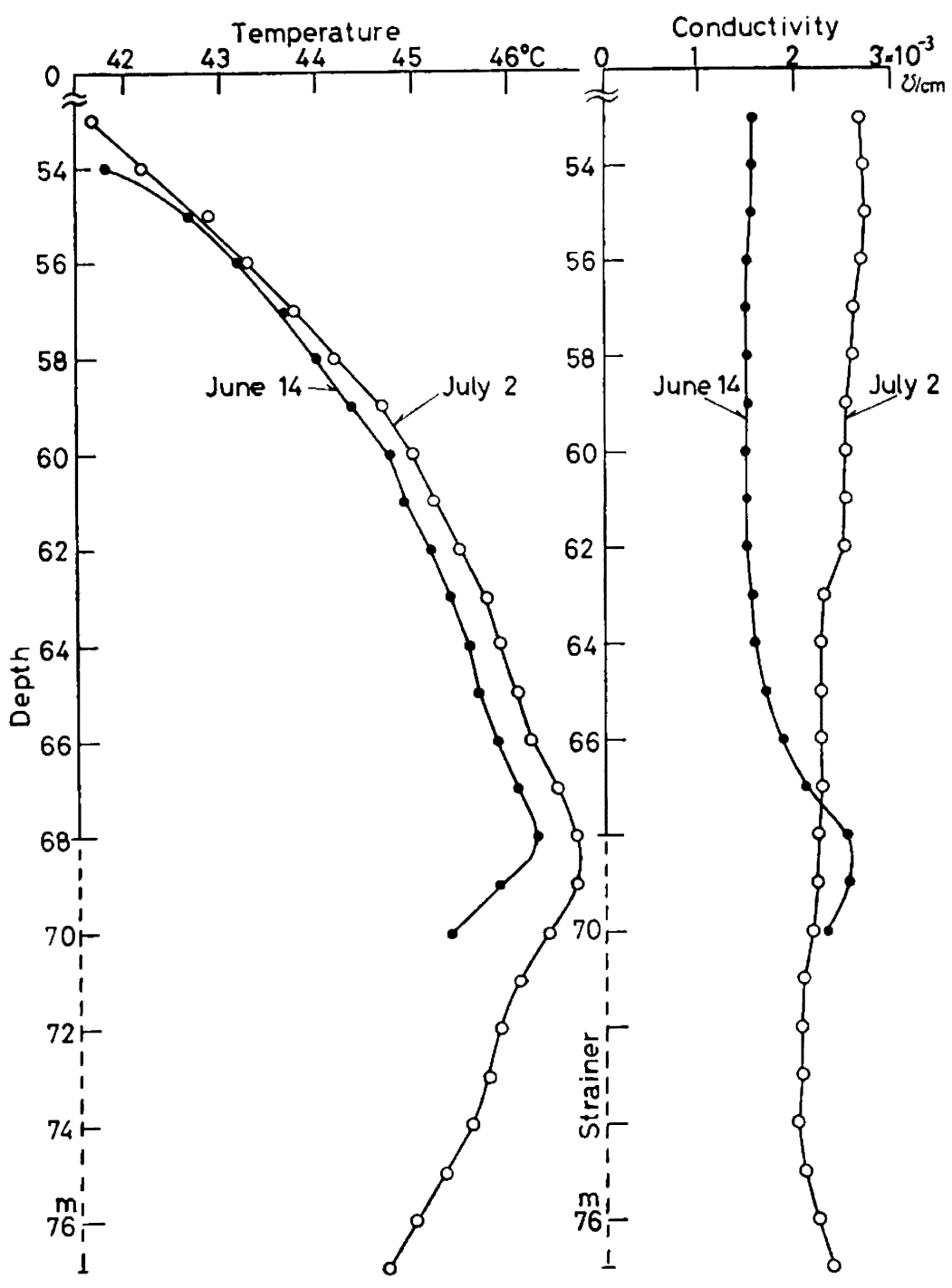

図一 7 号源泉の泉温及び比電導度垂直分布 っている。これでみるように，本格的な水蒸気爆発は1978年 7 月15日に始まり，8月から 9 月へかけ て最盛をきわめ，そして10月 5 日を最後として終息した。この間，爆発回数は 100 回近い。

困10はB 源泉の泉温その他の経時変化を示したものもある。この源泉では, 頭初 $50^{\circ} \mathrm{C}$ 弱であった泉 温は, 噴火活動も峠を越えた 9 月上旬になって上昇しはじめ, 爆発活動が終息した後も上昇を持続し て，11月上旬には $52.8^{\circ} \mathrm{C}$ とっている。しかし，まえの 6 号源泉にくらべると，昇温・泉温ともに劣 る。これは, 昇温期の遅れとも関係があろら。一方, 水位の変動はわずかであって, それも爆発活動 や泉温変化とは殆ど対応せず, 専ら湖水面の変動に追従しているかのようである。この間, 源泉水面 
表一 56 号源泉とB 源泉の水位 $(\mathrm{m})$

\begin{tabular}{|c|c|c|c|c|c|c|}
\hline 源泉 & & 6 号 & $*$ & & & \\
\hline 月日 & 地盤変動量 & 更正地盤標高 & 水面深度 & 水面標高 & 水面深度 & 水面標高 \\
\hline 5.25 & 0.284 & 138.763 & 53.150 & 85.613 & & \\
\hline 28 & 0.277 & .770 & .256 & .514 & & \\
\hline 6.10 & 0.257 & .790 & .021 & .769 & & \\
\hline 17 & 0.246 & .801 & 52.883 & .918 & 46.825 & 83.626 \\
\hline 25 & 0.234 & .813 & .854 & .959 & & \\
\hline 7. 1 & 0.225 & .822 & .847 & .975 & & \\
\hline 8 & 0.214 & .833 & .823 & 86.010 & & \\
\hline 15 & 0.203 & .944 & .850 & 85.994 & & \\
\hline 8. 19 & 0.148 & .899 & 53.050 & .849 & 47.045 & 83.406 \\
\hline 27 & 0.136 & .911 & .130 & .781 & 46.950 & .501 \\
\hline 9. 8 & 0.118 & .929 & .215 & .714 & 47.025 & .420 \\
\hline 22 & 0.096 & .951 & .340 & .611 & .010 & .441 \\
\hline 29 & 0.095 & .962 & .420 & .542 & .000 & .451 \\
\hline 10. 7 & 0.073 & .974 & .510 & .464 & .020 & .431 \\
\hline 21 & 0.051 & .996 & .590 & .406 & 46.960 & .491 \\
\hline 28 & 0.040 & 139.007 & .610 & .379 & .920 & .531 \\
\hline 11. 10 & 0.020 & .027 & .820 & .207 & .920 & .531 \\
\hline
\end{tabular}
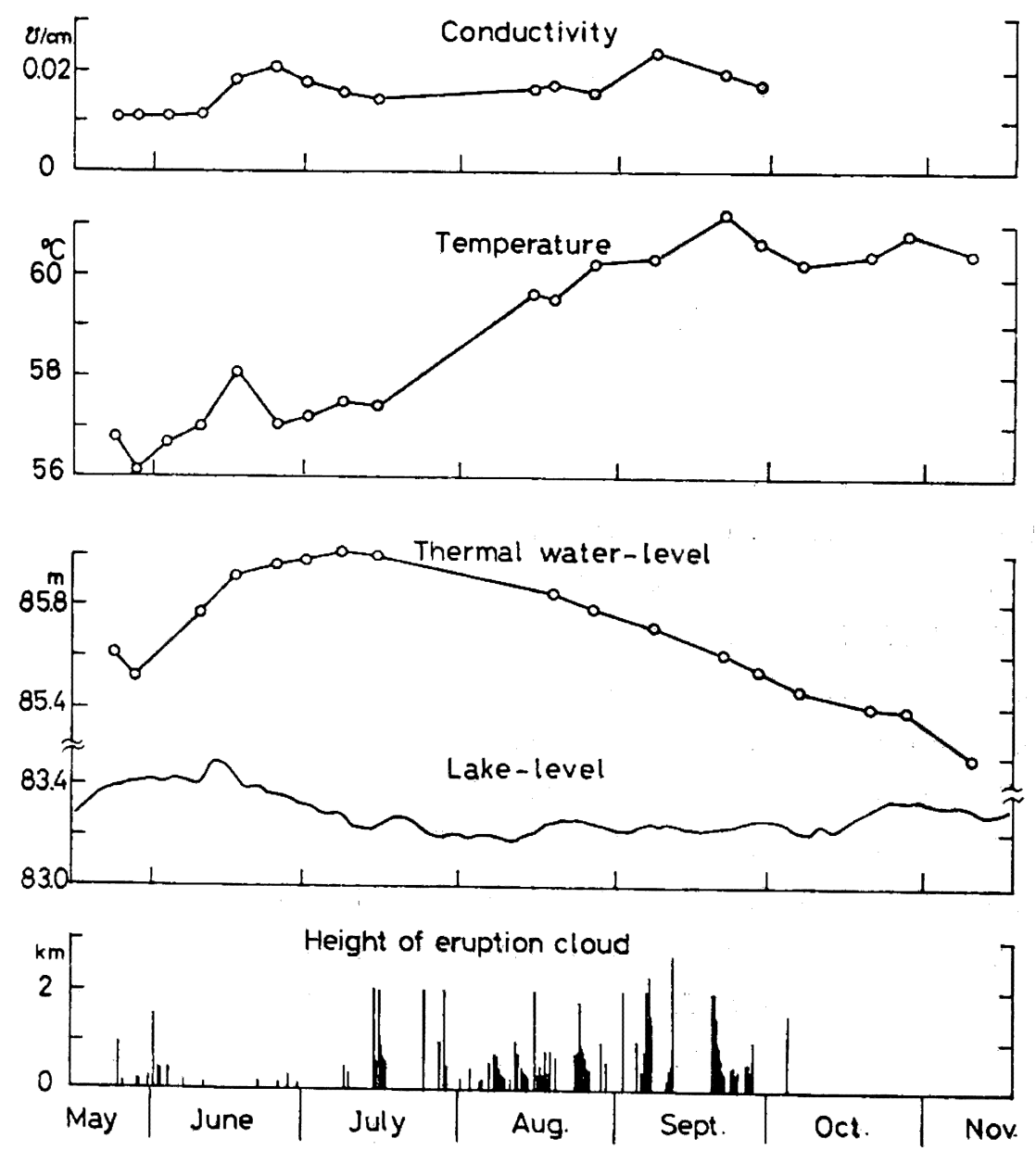

图-9 6 号源泉の泉温・比電 導度及び氷位の経時变 化 


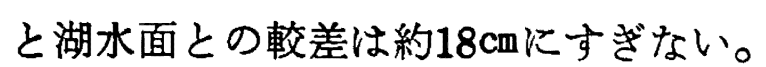
参考として, 四の最下段に有珠気象観 測所の日降水量を示したが，これと湖 水面の昇降とはほぼ対応している。

\section{4. 泉犋への影啐}

国内諸大学の地球化学研究者らは, 噴火後いちはやく研究グループを組織 して, 温泉・地下水・火山灰などの調 査研究をすすめている（松尾ほか：19 77）。また，北海道衛生部は行政上の 立場から，有珠山噴火による源泉その 他給湯施設の被害状況々対策, 源泉々 温・泉質などへの影響について，綿密 な現地調查を行っている（北海道衛生 部：1978）。そこで著者らは，この調 查資料にもとづいて，噴火にともなう 泉質の変化をうかがうことにする。表 6 は資料に掲載の泉質分析值の要約で，源泉番号は図と一致さ せて示す。
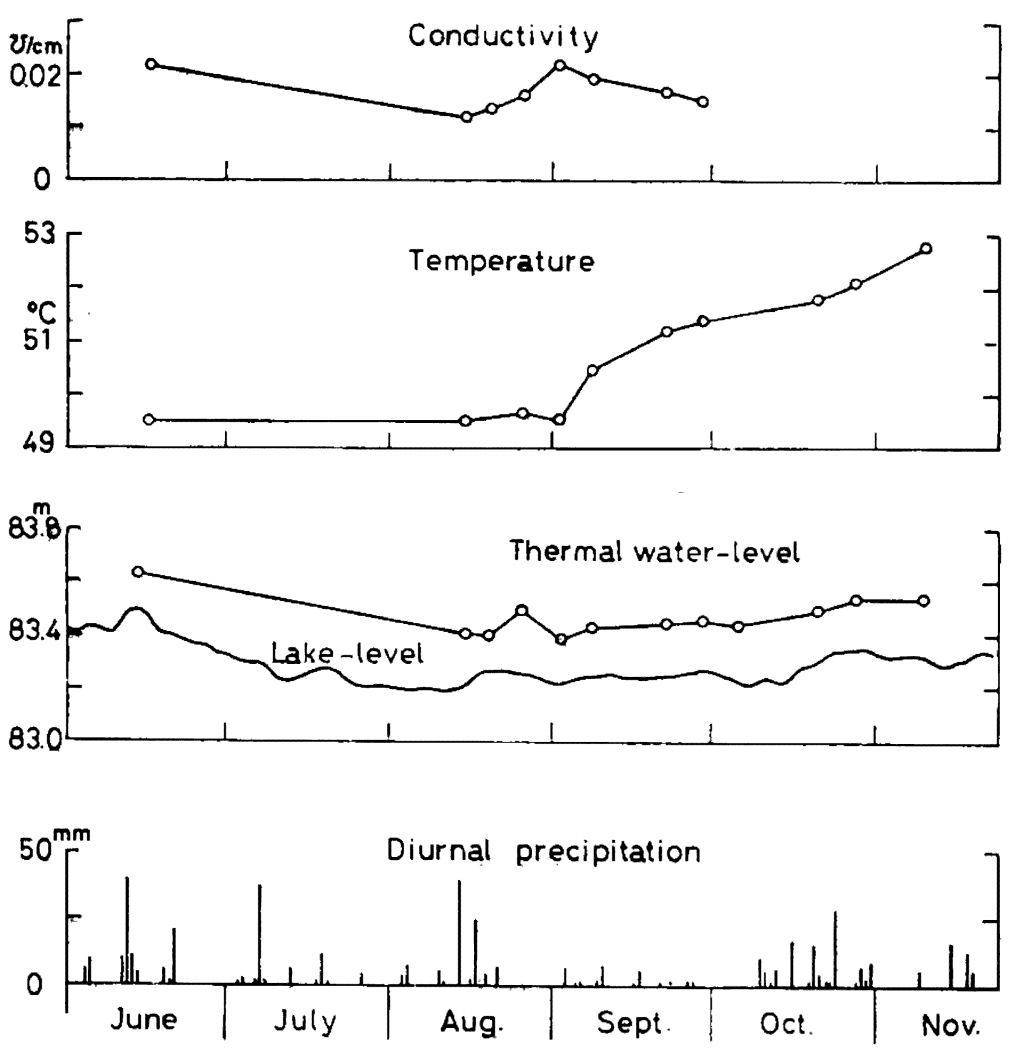

图-10 B 源泉の泉温・比電導度及び水位の経時変化 表一6 泉 質 の 推 移 (道立衛生研究所分析)

\begin{tabular}{|c|c|c|c|c|c|c|c|c|c|c|c|c|c|c|c|c|}
\hline \multirow{2}{*}{ 利用源泉 } & \multicolumn{4}{|c|}{ 泉 温 $\left({ }^{\circ} \mathrm{C}\right)$} & \multicolumn{3}{|c|}{$\mathrm{PH}$} & \multicolumn{3}{|c|}{$\mathrm{C} \ell^{-}(\mathrm{ppm})$} & \multicolumn{3}{|c|}{$\mathrm{SO}_{4}^{=}(\mathrm{ppm})$} & \multicolumn{3}{|c|}{$\mathrm{HCO}_{3}^{-}(\mathrm{ppm})$} \\
\hline & 0 & I & II & III & I & II & III & I & II & III & I & II & III & I & II & III \\
\hline 2 & 44.5 & 45.6 & 44.9 & 48.0 & 7.4 & 7.4 & 7.2 & 550 & 330 & 546 & 580 & 398 & 443 & 241 & 247 & 232 \\
\hline 3 & 48.4 & 48.5 & 48.9 & 50.2 & 7.4 & 7.4 & 6.4 & 205 & 204 & 220 & 406 & 393 & 303 & 344 & 338 & 799 \\
\hline 4 & 42.7 & 43.4 & & 49.0 & 7.4 & & 6.5 & 218 & & 220 & 371 & & 317 & 303 & & 775 \\
\hline 5 & 42.6 & 43. 3 & 43. 0 & 44.5 & 7.4 & 7.4 & 7.0 & 169 & 191 & 184 & 315 & 344 & 237 & 289 & 337 & 354 \\
\hline 6 & 49.5 & 51.4 & 51.9 & & 7. 3 & 7.4 & & 684 & 759 & & 659 & 672 & & 234 & 208 & \\
\hline 7 & 48.4 & 48.7 & 48.6 & 48.9 & 7.3 & 7.4 & 6.4 & 191 & 190 & 206 & 377 & 325 & 286 & $330^{\prime}$ & 299 & 647 \\
\hline 8 & 46. 0 & 46.5 & 47.0 & 48.5 & 7.2 & 7.2 & 6.4 & 184 & 204 & 248 & 361 & 351 & 323 & 351 & 338 & 964 \\
\hline 9 & 52.8 & 52. 1 & 53.0 & 53.6 & 7.4 & 7.6 & 7.4 & 557 & 780 & 652 & 525 & 573 & 543 & 234 & 182 & 214 \\
\hline 10 & 49. 2 & 48.5 & 50.6 & 50.2 & 7. 2 & 7.2 & 6.6 & 191 & 197 & 277 & 388 & 402 & 306 & 351 & 325 & 940 \\
\hline C & 40.0 & 39.0 & $39^{\circ} 0$ & 40.0 & 7.3 & 7.9 & 7. 2 & 1185 & 1139 & 1312 & 422 & 442 & 428 & 255 & 234 & 250 \\
\hline D & 44.0 & 43. 8 & 45.2 & 48.0 & 7.3 & 7.6 & 7.0 & 311 & 443 & 553 & 370 & 454 & 470 & 275 & 253 & 311 \\
\hline$E$ & 43. 0 & 41.8 & 43. 0 & 47.0 & 7.5 & 7.4 & 7.2 & 191 & 190 & 192 & 344 & 363 & 337 & 337 & 317 & 568 \\
\hline $\mathrm{F}$ & 42. 0 & 43. 2 & 43. 0 & 46.0 & 7.3 & 7.4 & 7.2 & 176 & 170 & 184 & 329 & 351 & 328 & 316 & 305 & 568 \\
\hline G & 26. 0 & 26.0 & 30.9 & 34.0 & 7.6 & 7.8 & 7.4 & 92 & 134 & 156 & 152 & 230 & 277 & 275 & 305 & 299 \\
\hline $\mathrm{H}$ & 25.5 & 25.5 & 24. 0 & 26.0 & 7.5 & 7.8 & 7.4 & 106 & 91 & 114 & 186 & 161 & 175 & 344 & 318 & 354 \\
\hline
\end{tabular}

O : 1977. 7. $31 \quad$ I $: 1977.10 .3 \sim 8 \quad$ II $: 1978.3 . \quad 8 \sim 11 \quad$ III $: 1978.8 . \quad 2 \sim 5$ 
表 6 において，まず泉温の動向をみると，1977噴火開始以降，ど源泉も何がしか昇温している。 そのうちでも初期の頃の昇温は，観光客の途絶で揚湯量が激減したためと思われるが，1978年春以降 の昇温は明らかに噴火の影響とみられる。

次に $\mathrm{PH}$ は，ど源泉も1978年 8 月時点で低下しており，そしてこれらのらちにその顕著なものの 存在が注目をひく。

化学成分のうち塩化物イオン $\left(\mathrm{Cl}^{-}\right)$と炭酸水素イオン $\left(\mathrm{HCO}^{-}\right)$については, 1978年 3 月までは 著しい増減はみられないが，8月時点で一斉に増加している。その増加傾向は, $\mathrm{C} \ell$-よりも $\mathrm{HC} \mathrm{O}^{-}$ において著しい。ところが硫酸イオン $\left(\mathrm{SO}_{4}^{-2}\right.$ は)，8 月時点において大半の源泉で減少している。

こうした PHならびに化学成分の濃度変化は，水蒸気爆発の開始と前後して，温泉水への炭酸ガス の供給が活発化した結果と考えられる。
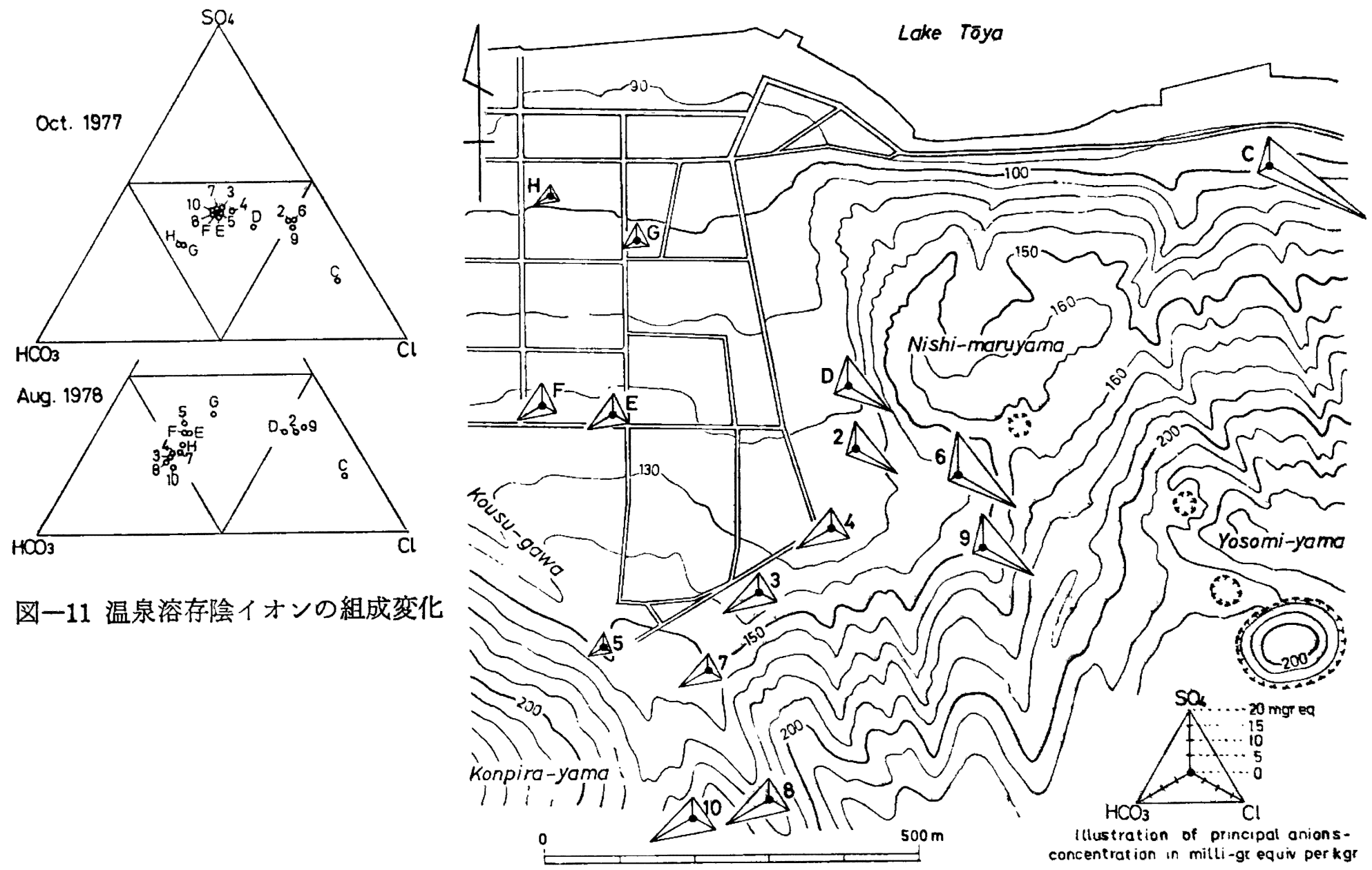

図一12 1978年 8 月に打ける温泉溶存陰イオンの漊度分布

さて，表 6 の陰イオン 3 成分の当量百分比を三角座標にプロットすると図11のよらになる。この図 は，水蓄気爆発を契機に泉質型がはっきり 2 群に分かれたことを示している。そして図12は，水蒸気 爆発後の1978年 8 月時点に拈ける各源泉の陰イオン 3 成分の当量濃度を夫々の源泉位置に示したもの で, $\mathrm{C} \ell^{-}$卓越型の温泉水は西丸山・四十三山近傍に分布し, $\mathrm{HCO}_{3}{ }^{-}$卓越型の温泉水は小有珠川扇頂 部近傍に分布していることがわかる。このよらな泉質型変動の出現は，すでに福富ら（1957）も指摘 しているように，洞爺湖温泉の本源熱水系には少くとも 2 系統が存在することを明確に示畯するもの 
である。おそらく，系統のひとつは四十三山活動の遗産であり，いまひとつは金比羅山活動の遺産で あって, 両者ともに今回の噴火活動の直接あるいは間接的刺戟をうけ, 温泉水の化学成分や温度に変 化をもたらしたと考㝋られる。

\section{あとがき}

洞爺湖温泉は，昭和51年温泉保護地域に指定されて，新規掘削や増掘は原則として認められていな い。ところが今回の噴火によって利用源泉井のらち数本が使用不能となったため, 特例によって代替 掘削が認められ，地盤変動の鎮静化を待らながらボーリング工事が次々と進められている。そして， これまで不詳だった温泉貯留層の実態が逐次解明されつつある。したがって，これらの代替ボーリン グがすべて完了した暁は，温泉の涌出機構はいっそう詳かとなり，今後の温泉管理に大きく資するこ ととなろう。

この報文をまとめるに当り, 北海道大学有珠火山観測所渡辺秀文氏からは地盤変動状況に関して種 々ご教示をいただいた。また，北海道衛生部薬務課長友山唯之氏，北海道立衛生研究所生活科学部長 井上勝弘氏，同鉱泉化学科長北山正治氏には，貴重な調査資料引用のご承認をたまわった。なおまた 洞翁湖温泉利用協同組合専務理事森谷寛氏からは現地調查に多大の便宜をたまわった。ここに記して 各位に深く感謝の意を捧げる。

\section{参 考 文 献}

石川俊夫 (1963)：洞爺湖温泉の成生と変遷, 物理探鉱, 16-1

太田良平（1956）：1 15 万地質図幅「虬田」地質調査所

鈴木醇・石川俊夫・鈴木淑夫・勝井義雄（1957）：洞爺湖温泉地質班調査報告, 北海道温泉調査報 告, VI

土居繁雄（1960）：洞爺湖温泉の泉温低下について，地下資源調査所報告， 24

福富孝治・藤木忠美・須川明 (1957：) 洞爺湖温泉付近の $1 \mathrm{~m}$ 深地温調查, 北海道温泉調查報告 VI 北海道衛生部（1078）：有珠噴火に伴亏洞爺湖・壮瞥地域温泉等調查結果（手記，未公表）

北海道電力㧣：洞爺湖水位月報

松尾禎士ほか14名（1977）：1977年有珠山噴火直後の地下水・温泉および火山灰の地球化学的研究 火山, II, 22-4

横山 泉・勝井義雄・大場与志男・江原幸雄 (1973：）有珠山, 北海道防災会議

横山 泉 (1978）：1977有珠山噴火活動の予測に関連して，火山， I，23-1

（受付：1979年12月 1 日，受理：1980年 7 月12日） 